\title{
Impact of Economic Liberalization on Technical Efficiency of Firms: Evidence from India's Electronics Industry
}

\author{
Dipayan Datta Chaudhuri \\ Department of Economics, Indian Institute of Management Indore, Indore, India \\ Email: dipayan@iimidr.ac.in
}

Received 11 May 2016; accepted 12 June 2016; published 15 June 2016

Copyright (C) 2016 by author and Scientific Research Publishing Inc.

This work is licensed under the Creative Commons Attribution International License (CC BY). http://creativecommons.org/licenses/by/4.0/

(c) (i) Open Access

\section{Abstract}

The purpose of the paper is to analyze the impact of economic liberalization on technical progress and technical efficiency of electronics hardware manufacturing firms in India. In this study, Translog stochastic frontier production function is estimated in order to measure technical progress and technical efficiency of firms in an era of economic liberalization. The results indicate that electronics hardware manufacturing firms in India have experienced a significant improvement in technical progress during 2002-2010 but the average level of technical efficiency of firms has declined during the same period. The study therefore, concludes that a number of firms have failed to appropriate the benefits of technical progress in India's electronics industry. It has also been observed that implementation of the Information Technology Agreement (ITA) of World Trade Organization (WTO) does not have any significant impact on technical efficiency of firms operating in the electronics industry.

\section{Keywords}

Technical Efficiency, Technical Progress, Translog Stochastic Frontier Production Function

\section{Introduction}

In the year 2005, tariff rates on imported goods (known as "customs duty" in India) on a wide range of electronics products were reduced to zero due to the implementation of the Information Technology Agreement (ITA) of World Trade Organization (WTO) ${ }^{1}$. This elimination of tariffs is likely to intensify competition in the electronics industry as it would result in the influx of cheaper imported electronic products. It is therefore, imperative for

${ }^{1}$ The text of the ITA is available at http://www.wto.org/english/docs_e/legal_e/itadec_e.htm. 
this sector to improve its competitiveness in order to face the challenges from duty-free imports of electronic products as the sector is highly import intensive ${ }^{2}$. The competitiveness of a firm can be enhanced if there is an improvement in the level of technical efficiency.

The growth of output of a firm over time can be decomposed into change in technical efficiency, technical change and input growth [1]. The total factor productivity growth (TFPG) is the residual between the changes in output net of changes in inputs which is a measure of our ignorance [2]. TFPG consists of two distinct components: change in technical efficiency and technical change. Technical progress does not necessarily imply an improvement in technical efficiency for a firm. It is possible that technical progress can coexist with deteriorating technical efficiency. Similarly, technical regress can also coexist with an improving technical efficiency performance.

The objective of this study is to analyze the impact of economic liberalization on technical efficiency of firms in the electronics hardware industry. Technical efficiency refers to the ability of a firm to minimize use of inputs in the production of a given output vector, or the ability to obtain maximum output from a given input vector. We have estimated Translog stochastic frontier production function in order to measure technical efficiency of firms. In this approach the best-practice production frontier has been estimated and then how far short an individual firm falls below this frontier has been considered. A firm is considered to be technically efficient if it is on the frontier [3]. This study has explored whether the firms in India's electronics hardware sector have experienced an improvement in technical efficiency during the period of economic liberalization. This study has also tried to identify the determinants of technical efficiency for a firm operating in this sector. This paper has examined whether technical efficiency of firms is dependent on imports of technology, capital-goods and raw materials. This study has further analyzed whether there is a significant difference in technical efficiency between foreign firms and domestic firms and between domestically owned private and public sector firms. This paper has also examined whether size of the firm has any significant influence on its technical efficiency.

This paper is organized in the following manner. Section 2 analyzes the performance of the electronics hardware sector of India. In Section 3, we briefly review the studies on technical efficiency in the context of economic liberalization. Specification and estimation of the model are discussed in Section 4. Section 5 deals with sources of data and methods of measurement of variables. The main findings from empirical analysis are presented in Section 6 and Section 7 concludes the paper.

\section{The Electronics Hardware Industry in India}

Evolution of the policies for the electronics industry in India can be divided into three phases [4]. The first phase is known as the period of "import substitution" which lasted till the late 1970s. During this period, the objective was to establish a self-reliant electronics sector and the strategy was to achieve public sector led growth in a protective environment. The second phase can be termed as the period of "controlled liberalization" during 1980s. In this phase, the emphasis was laid on scale economies, easier access to foreign technology and capital as well as free entry for private sector enterprises. The third phase is the "era of globalization" which was initiated in the year 1991. In this phase, there was removal of industrial licensing for most of the products except few products of strategic significance. Further liberalization of foreign direct investment and a series of fiscal and trade policy reforms were initiated in order to allow free operation of market forces as these reform measures were expected to improve competitiveness of India's electronics industry internationally.

A National Task Force on Information Technology and Software Development was constituted in 1998. In the same year, the Department of Electronics was merged with the Department of Information Technology as a part of the Ministry of Communications and Information Technology, Government of India. The National Task Force also set up a hardware panel which recommended bringing tariffs on inputs and capital goods to zero per cent, simplification in Export and Import (EXIM) policy and customs procedures.

Since March 2005, over 800 products covering 217 tariff lines are being imported duty free with the implementation of the first phase of World Trade Organization's (WTO) Information Technology Agreement (ITA-1) coming into full force ${ }^{3}$. All goods required in the manufacture of ITA-1 items have been exempted from customs duty subject to actual user condition. Customs duty on inputs and capital goods used for manufacturing of

\footnotetext{
${ }^{2}$ In India, around 90\% of components/parts are imported. See "Country Report on the Indian Electronics Sector" by ELCINA Electronics Industries Association of India, May 2007. http://www.cfsd.org.uk/Indian_AEDE_Report.pdf.

${ }^{3}$ ibid.
} 
electronic goods is reduced to zero. Products that no longer enjoy tariff protection constitute telecom, personal computers, strategic defense, industrial as well as some consumer equipments [5] [6]. The Department of Information Technology has been re-named as the Department of Electronics and Information Technology in the year 2012.

It has been observed that the annual compound growth rate of the electronics hardware sector has declined marginally from $13.1 \%$ to $11.2 \%$ between $1990-97$ and 1997-02 [4]. However, this sector has recorded a compound growth rate of $14 \%$ per annum during $2002-10^{4}$. The domestic production of electronics goods is falling short of its demand leading to a steady increase in its imports. Figure 1 shows that imports of electronic goods have far outstripped its exports during 2002-2013 causing widening of trade deficits for this sector. It has been mentioned in the National Policy on Electronics (NPE), 2012 that if the electronics hardware sector continues to grow at the current rate, then the electronics import may far exceed oil imports by 2020. The electronics hardware sector can be classified into key sub-sectors namely consumer electronics, computer hardware, electronic components, communication equipments, industrial electronics and strategic electronics.

It is interesting to note that in contrast to the electronics hardware sector, the software sector of India has shown remarkable progress during the period of economic liberalization. The compound growth rate of this sector is $22.5 \%$ per annum during $2002-10^{5}$. This high growth rate has enabled India to emerge as a dominant player in the world in the software sector. India's software is highly export oriented and the share of exports is around $80 \%$ out of the total turnover of this sector. The software sector has benefitted largely due to the availability of cheap manpower in India. However, this advantage in manpower cost is slowly disappearing with the increase in the salary levels of software engineers. The only way for India to maintain her leadership position in the software sector is to move up the value chain [7].

\section{Review of Studies on Technical Efficiency in an Era of Economic Liberalization}

In the case of India, economic reform measures initiated in the year 1991 have provided an opportunity to study the impact of economic liberalization on productivity growth of Indian firms. A number of studies based on firm-level data (Krishna and Mitra [8]; Topalova [9]; Sivadasan [10]; Topalova and Khandelwal [11]) have observed that lowering of tariffs has led to faster productivity growth. Studies (Ray [12]; Siddharthan and Lal [13]; Goldar et al. [14]; Banga [15]; Kato [16]) have also shown that import of disembodied technology, Research and Development (R \& D) intensity and availability of wider varieties of higher quality imported inputs have favourable impact on productivity growth of Indian firms. However, Balakrishnan and Suresh Babu [17]; Srivastava [18] and Balakrishnan et al. [19] could not find evidences of a widespread increase in the rate of productivity growth across all sectors. The productivity of firms has improved in sectors where the market structures have become more competitive as a result of deregulation ${ }^{6}$.

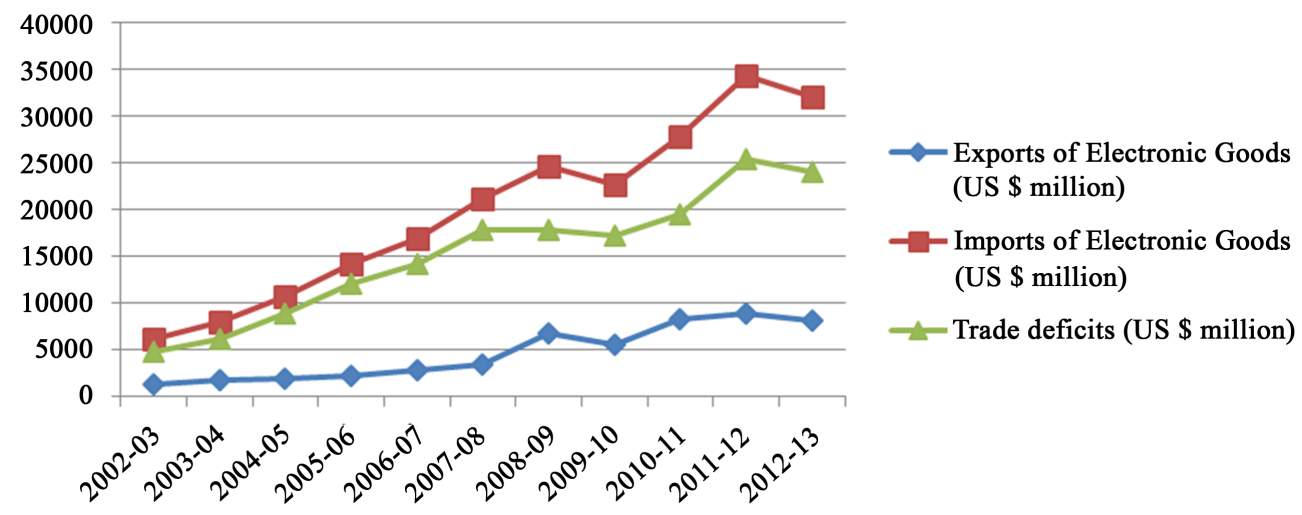

Figure 1. Exports and imports of electronic goods. Source: Handbook of Statistics for Indian Economy, Reserve Bank of India.

\footnotetext{
${ }^{4}$ The growth rates are measured at current prices as unlike other industries, prices recorded a declining trend in the electronics sector. ${ }^{5}$ The growth rate is computed from Annual Report, Department of Electronics and Information Technology, Government of India (various issues).

${ }^{6}$ See Datta Chaudhuri [20] for a review of studies on productivity growth of Indian manufacturing firms in an era of economic reforms.
} 
In the case of the electronics hardware sector of India, Mazumdar [21] [22] has examined the contribution of change in technical efficiency and technical progress to output growth during 1993-2004. In another study on the Indian electronics sector, Dwivedi [23] has analyzed the trend in technical efficiency, technological change and total factor productivity growth of firms by using the Data Envelopment Analysis (DEA). None of these studies have dealt with the impact of implementation of ITA of WTO on technical efficiency of firms in the electronics industry of India. This study will address this issue by analyzing whether the implementation of ITA in the year 2005 has resulted in a significant improvement in technical efficiency of firms in the electronics sector of India.

\section{Empirical Model}

The factor use efficiency of a firm or an industry is measured by the total factor productivity growth (TFPG). According to Solow [24], TFPG can be measured as "any kind of shift" in the production function over time which is interpreted as technical change. It was however, assumed that all producers operate on the production frontier i.e. technically efficient. But in real scenario not all producers can optimize i.e. minimize input bundles to produce various outputs or maximize output producible from available input bundles, given the technology. Leibenstein [25] argued that production is bound to be inefficient due to asymmetric information, lack of proper monitoring or motivation, agency problems etc. Such inefficiencies taken together were termed as "X-inefficiency”.

Farell [26] suggested that the deviation of observed points from the points on the frontier constructed from the observed points can be considered as a measure of technical efficiency. In this study a non-parametric linear programming technique was used which led to the development of DEA by Charnes, Cooper and Rhodes [27]. A parametric approach to frontier production function incorporating a specific functional form was first used by Aigner and Chu [28] which led to the emergence of stochastic frontier analysis (SFA). SFA originated from the studies of Meeusen and Broeck [29] and Aigner et al. [30]. Subsequently, Battese and Corra [31], Pitt and Lee [32], Schmidt and Sickles [33], Cornwell et al. [34], Kumbhakar [35], Battese and Coelli [36], Kumbhakar et al [37], Huang and Liu [38] and Battese and Coelli [39] worked on the development of the SFA. Stochastic frontier models separate technical inefficiency from noise by incorporating two error components-one reflecting inefficiency and the other reflecting measurement error or shocks beyond the control of managers [40].

In this study, we use a stochastic frontier production function along with an inefficiency model as specified by Battese and Coelli [39] in order to measure technical change, technical efficiency and also to identify determinants of technical efficiency for firms belonging to the electronics hardware industry. It has been assumed that the stochastic frontier production function is of translog type as this functional form imposes fewer restrictions.

$$
\begin{aligned}
\log Q_{i t}= & \beta_{0}+\beta_{k} \log K_{i t}+\beta_{l} \log L_{i t}+\beta_{m} \log M_{i t}+\beta_{t} t_{i t}+1 / 2 \beta_{k k}\left(\log K_{i t}\right)^{2} \\
& +1 / 2 \beta_{l l}\left(\log L_{i t}\right)^{2}+1 / 2 \beta_{m m}\left(\log M_{i t}\right)^{2}+1 / 2 \beta_{t t} t_{i t}^{2}+\beta_{k l}\left(\log K_{i t}\right)\left(\log L_{i t}\right) \\
& +\beta_{k m}\left(\log K_{i t}\right)\left(\log M_{i t}\right)+\beta_{k t}\left(\log K_{i t}\right) t_{i t}+\beta_{l m}\left(\log L_{i t}\right)\left(\log M_{i t}\right) \\
& +\beta_{l t}\left(\log L_{i t}\right) t_{i t}+\beta_{m t}\left(\log M_{i t}\right) t_{i t}+V_{i t}-U_{i t}
\end{aligned}
$$

where the subscript $i$ and $t$ indicate the observation for $i$-th firm in the $t$-th year, $Q_{i t}, K_{i t}, L_{i t}$ and $M_{i t}$ are output, capital stock, labour and raw-materials consumed respectively by $i$-th firm and $\boldsymbol{t}$ is the time trend included in the equation to allow the frontier to shift over time and the shift is interpreted as technical change. The $V_{i} \mathrm{~s}$ are assumed to be independently and identically distributed normal random variables with mean zero and variance $\sigma_{v}^{2}$.

The $U_{i t}$ s are non-negative random variables associated with technical inefficiency of production, which are assumed to be independently distributed, such that $U_{i t}$ is obtained by truncation (at zero) of the normal distribution with mean, $Z_{i t} \delta$ and variance, $\sigma^{2}$ where $Z_{i t}$ is a $(1 \times m)$ vector of explanatory variables associated with technical inefficiency of production of firms over time and $\delta$ is $(m \times 1)$ vector of unknown co-efficients. The technical inefficiency effects, $U_{i t} \mathrm{~s}$ are assumed to be a function of a set of explanatory variables, the $Z_{i t} \mathrm{~s}$ and an unknown vector of co-efficients $\delta$.

The technical inefficiency effect, $U_{i t}$, in the stochastic frontier model (1) is specified as:

$$
U_{i t}=Z_{i t} \delta+W_{i t}
$$


In this study, the $Z$ variables, which are involved in the inefficiency model are defined in the next section. Here it is assumed that the $Z$-variables are not related to the input variables in the frontier production function (1). So, the inefficiency model (2) specifies a neutral stochastic frontier, rather than the non-neutral model, as proposed by Huang and Liu [38].

The method of maximum likelihood has been used for simultaneous estimation of the parameters of the stochastic frontier and the model for technical inefficiency effects has been applied by using Frontier 4.1 (Coelli [41]). The likelihood function is expressed in terms of the variance parameters,

$$
\sigma_{s}^{2}=\sigma_{v}^{2}+\sigma^{2} \text { and } \gamma=\sigma^{2} / \sigma_{s}^{2}
$$

The technical efficiency level of the $i$-th firm at time $t\left(T E_{i t}\right)$, is defined as the ratio of the actual output to the potential output thus, $T E_{i t}$ is defined as

$$
T E_{i t}=\mathrm{e}^{-u_{i t}}
$$

The stochastic frontier model as specified in Equation (1), allows for non-neutral technical change. Technical change is neutral if all $\beta_{i t} \mathrm{~s}\left(\beta_{k t}, \beta_{l t}, \beta_{m t}\right)$ are equal to zero. Technical change is input-i using (saving), if $\beta_{i t}$ is positive (negative). In this production function the co-efficients $\beta_{k}, \beta_{l}, \beta_{m}$ represent elasticities of capital, labour and raw materials respectively. The production function reduces to the Cobb-Douglas function with neutral technical change if $\beta_{k k}, \beta_{l l}, \beta_{m m}, \beta_{t t}, \beta_{k l}, \beta_{k m}, \beta_{k t}, \beta_{l m}, \beta_{l t}$ and $\beta_{m t}$ are equal to zero.

\section{Data and Variables}

The data for firms in the electronics hardware industry of India have been collected from Prowess database provided by Centre for Monitoring Indian Economy (CMIE), Mumbai, India. Prowess is a database of large and medium Indian firms. It contains data of all companies traded on India's major stock exchanges and several others including public sector enterprises. In this study, we use panel data of electronics hardware manufacturing firms from the year 2002-03 to 2009-10. The panel is unbalanced and it consists of data from 100 firms. Out of 100 firms, domestic firms are 90 (of which 8 are public sector firms) and the remaining 10 are foreign firms. Our sample of firms is drawn from four sub-sectors of the electronics sector namely, communication equipments (12 firms), computer hardware (9 firms), consumer electronics (4 firms) and other electronics ${ }^{7}$ (75 firms). Data are collected for eight years from 2002-03 to 2009-10. The year 2002-03 is taken as the benchmark year for this study as there was revival of the growth rate for the manufacturing sector from that year after a period of lackluster performance during 1997-2002 (Nagaraj [42]) ${ }^{8}$. Moreover, it was only in 2001-02 all quantitative restrictions on imports for this sector were done away with. So, the next year i.e. 2002-03 is taken as the benchmark year for this study. The procedures followed in the measurement of variables used in the estimation of the frontier production function i.e. Equation (1) and the inefficiency model i.e. Equation (2) are explained here.

Output (Q): Output is measured as the value of sales plus closing stock minus opening stock of inventories of finished products. The data are then deflated by wholesale price indices $(1993-94=100)$ in order to derive value of output at constant prices ${ }^{9}$. The wholesale price indices are collected from www.indiastat.com.

Inputs: The three categories of inputs included in the model are namely, capital, labour and raw materials. The data on gross fixed asset (GFA) is collected for estimating capital stock of firms. The capital stock of each firm is estimated following the perpetual inventory accumulation (PIA) method. The details of estimation of capital stock are given in Appendix.

The data on salary and wages are collected since the Prowess database does not contain data on number of employees in the firms. We have estimated the number of employees for each firm from the data of salary and wages in the following manner. The data on "total emoluments" and "total persons engaged" are collected from Annual Survey of Industries (ASI) of the Central Statistical Organization at three-digit level from the sectors belonging to electronics ${ }^{10}$. Using these data, emoluments per person is computed and then, salary and wages da-

\footnotetext{
${ }^{7}$ Other electronics sub-sector includes industrial electronics and electronic components.

${ }^{8}$ The growth rate of the manufacturing sector increased from 5.6\% per annum during 1997-2002 to 8.9\% per annum during 2003-08.

${ }^{9}$ The value of output data of firms operating in computer and consumer electronics sub-sectors are deflated by wholesale price indices of computer and computer-based system and that of TV sets respectively. For other firms, the wholesale price index of electronic equipments is used as a deflator. Same price indices are used for measuring sales turnover of firms at constant prices.

${ }^{10}$ Central Statistical Organization (CSO) under the Ministry of Statistics and Programme Implementation, Government of India releases Annual Survey of Industries (ASI) every year in which codes are assigned to different industrial sectors. For our study, the relevant codes are 261 (electronic components), 262 (computer and peripheral equipments), 263 (communication equipments) and 264 (consumer electronics).
} 
ta of each firm are deflated by emoluments per person data in order to derive an estimate of the number of employees in the firm for each year of our study period. Studies have shown that foreign owned firms pay more to their employees compared to domestic firms (Girma et al. [43], Lipsey and Sjohlom [44]). So, emoluments per person of foreign owned firms are increased by $10 \%$ in order to account for this factor (Goldar et al. [14]). The number of employees in the foreign owned firms is estimated with this adjustment. Electronic components are generally used as raw materials in this sector. The data on raw materials consumed are deflated by the wholesale price index of electronic items.

The following variables are used in the efficiency model for explaining the differences in the inefficiency levels of firms.

Import intensity: In this study, import intensity is measured with the help of three variables-capital-goods import intensity (KIMPINT), input import intensity (IMPINT) and technology import intensity (TECHIMP). Import of capital goods and raw-materials are deflated by unit value indices of imports ${ }^{11}$. The data on technology import i.e. expenditures on royalties, technical know-how fees, license fees are adjusted by using the Real Effective Exchange Rate (REER) since the exchange rates of Indian rupee have fluctuated during the study period. The REER of Indian rupee is based on thirty-six currency bilateral trade weights. The REER data are collected from the Handbook of Statistics on Indian Economy, published by the Reserve Bank of India. All these variables are divided by sales turnover measured at constant prices in order to derive three different measures of import intensities. It is hypothesized that there is a direct relationship between import intensity of a firm and its technical efficiency.

A time dummy (TD) is used in the study in order to capture the impact of implementation of ITA on technical efficiency of firms. So, TD takes the value 1 for 2005-06 to 2009-10 and 0 for 2002-03 to 2004-05. It is expected that technical efficiency of firms has improved after 2005 since firms have easier access to cheaper imported inputs and capital goods.

R \& D intensity: R \& D intensity (RNDINT) is measured as the ratio of R \& D expenditure to sales turnover ratio, both are measured at constant prices ${ }^{12}$. As a firm spends more on $\mathrm{R} \& \mathrm{D}$, its knowledge on technology becomes richer. As a result of $\mathrm{R} \& \mathrm{D}$ activities a firm can benefit from the achievement of new technological processes, introduction of new products and improvements to existing product lines (Jang et al. [45]). So a firm with higher R \& D intensity is likely to be technically more efficient. It has been assumed that there is a time lag of one year between $\mathrm{R} \& \mathrm{D}$ activities of a firm and its technical efficiency.

SIZE: The logarithm of sales turnover of a firm measured at constant prices (LSALES) is taken as a measure of its SIZE. Empirical studies have shown that technically more efficient firms tend to be large (Pitt and Lee [32], Lundvall and Battese [46]). It is therefore, hypothesized that larger firms are technically more efficient as such firms can derive benefits from scale economies.

Foreign firms: Foreign firms are expected to be more efficient compared to the domestic firms because of their superior technology and managerial practices. In this study a dummy variable FOR is used in order to capture the inter-firm differences in technical efficiency. The dummy variable takes the value 1 if the share of foreign equity is greater than $20 \%$ and 0 otherwise ${ }^{13}$.

Public sector firms: It will be interesting to explore whether public sector firms are technically less efficient compared to private sector firms, since such firms are bound by various rules and regulations. A dummy variable PUB takes the value 1 for public sector firms and 0 otherwise.

\section{Results}

The frontier production function defined by the Equation (1) and the inefficiency model defined by the Equation (2) are estimated simultaneously by using the maximum likelihood estimation method for electronics hardware manufacturing firms.

Since technical efficiency estimates are sensitive to the specification of the production function we have con-

\footnotetext{
${ }^{11}$ Imports of capital goods and raw-material inputs are deflated by unit value indices $(1999-00=100)$ of import of machinery and telecom, sound recording/reproducing apparatus \&equipments respectively.

${ }^{12} \mathrm{R} \& \mathrm{D}$ expenditure data are deflated by weighted average of wholesale price index (WPI) of machinery and machine tools and consumer price index (CPI) of industrial workers. It is observed that the salaries and other benefits of the R \& D staff account for about $70 \%$ of total R\&D expenditure. So the weights assigned to CPI of industrial workers and WPI of machinery and machine tools are 0.7 and 0.3 respectively.

${ }^{13}$ Out of ten foreign firms, the share of foreign equity is less than $25 \%$ for one firm only.
} 
ducted the test for variances restrictions on the translog production frontier to check the appropriateness of the model in accordance with the data. For this we use the generalized likelihood-ratio (LR) as defined here:

$$
\lambda=-2[\mathrm{RLLF}-\mathrm{ULLF}]
$$

where,

RLLF = the log likelihood value of the restricted frontier model as specified by the null hypothesis $\mathrm{H}_{0}$ and,

$\mathrm{ULLF}=$ the $\log$ likelihood value of unrestricted frontier model value allocated as hypothesis $\mathrm{H}_{1}$.

If the sample size is large, it can be shown that the test statistics $\lambda$ follows the Chi-square $\left(\chi^{2}\right)$ distribution with degrees of freedom equal to the number of restrictions imposed by the null hypothesis.

The first null hypothesis that frontier production function is of Cobb-Douglas type with non-neutral technical change is rejected by the data for the electronics sector thereby, accepting the translog functional form (Table 1). The estimates of parameters of the translog type stochastic frontier production functions for the electronics sector are given in Table 2. Stochastic production frontier has been estimated instead of deterministic production function since the null hypothesis of no technical inefficiency effects is rejected for the translog production function (Table 3).

It can be observed from Table 2 that the co-efficient of the time variable $t_{i t}$ is positive and statistically significant for electronics hardware manufacturing firms. This indicates that the rate of technical progress is positive and statistically significant for this sector during the study period. There is an outward shift in the production frontier in the case of technical progress as the frontier firms experience upgradation of technology. The rate of technical progress has however decelerated over time since the co-efficient of $t_{i t}^{2}$ variable is found to be negative and statistically significant. The co-efficient of $\log L_{i t}$ (i.e. labour elasticity) is positive and significant at $1 \%$ level whereas the co-efficient of $\log K_{i t}$ is not statistically significant. This indicates that labour-rather than capital has played more dominant role in this industry. The co-efficient of $\log M_{i t}$ is also found to be positive and statistically significant. There exits diminishing marginal productivities for capital and labour since the co-efficients of $\left(\log K_{i t}\right)^{2}$ and $\left(\log L_{i t}\right)^{2}$ are negative and statistically significant. However, the co-efficient of $\left(\log M_{i t}\right)^{2}$ is found to be positive and statistically significant. The co-efficient of $\left(\log K_{i t}\right)\left(\log L_{i t}\right)$ is positive and statistically significant. This suggests that capital and labour are substitutes to each other. The negative co-efficients of $\left(\log K_{i t}\right)\left(\log M_{i t}\right)$ and $\left(\log L_{i t}\right)\left(\log M_{i t}\right)$ indicate that raw materials are complement for use of both capital as well as labour. The production function seems to be capital saving since the co-efficient of $\left(\log K_{i t}\right) t_{i t}$ is negative and statistically significant.

In the inefficiency model in Table 2, a positive co-efficient indicates an increase in inefficiency since the variables are determinants of inefficiency. The co-efficient of time $t_{i t}$ is positive and significant which indicates that in spite of experiencing technical progress, the average efficiency of firms has declined in the electronics sector. So, a number of firms have failed to appropriate the benefits of technical progress. The distance from the frontier has increased for an inefficient firm since there has been outward shift of the production frontier as other firms have experienced technical progress. The sign of time dummy (TD) is negative but not significant hence, there has not been any significant improvement in average efficiency of firms after 2005-06. The impact of economic liberalization is captured with the help of three variables KIMINT, TECHINT and IMPINT. It is observed that the co-efficients of KIMINT and TECHINT are negative and significant, whereas the co-efficient of IMPINT is positive and significant. So, imports of embodied and disembodied technology have resulted in an improvement of technical efficiency of firms in the electronics sector but technical efficiency is lower for firms, which are highly dependent on import of raw materials. The extent of value added is very limited as such firms are primarily engaged in assembling of imported inputs ${ }^{14}$. It has been observed that manufacturers of electronic products are turning into assemblers of the same products [6]. The co-efficient of R \& D intensity (RNDINT) is positive and significant for the electronics sector. It is surprising to find that R \& D seems to reduce efficiency

Table 1. Statistics for tests of hypothesis: Cobb-Douglas $\mathrm{H}_{0}\left(\beta_{k k}=\beta_{l l}=\beta_{m m}=\beta_{t t}=\beta_{k l}=\beta_{k m}=\beta_{k t}=\beta_{l m}=\beta_{l t}=\beta_{m t}=0\right)$.

\begin{tabular}{|c|c|c|c|c|}
\hline Null Hypothesis & Log-Likelihood Value ${ }^{1}$ & Test Statistic & Critical Value $^{2}$ & Decision \\
\hline Cobb-Douglas production function $\left(\mathrm{H}_{0}\right)$ & -321.78 & 78.26 & 18.31 & Ho Rejected \\
\hline
\end{tabular}

Notes: ${ }^{1}$ Log-likelihood value under null hypothesis; ${ }^{2}$ Critical value of the test statistic at $5 \%$ level of significance.

${ }^{14}$ It is mentioned in the National Policy on Electronics, 2012 that "the actual value-addition in the domestically produced electronic product is very low, ranging between 5 to $10 \%$ in most cases”. http://www.deity.gov.in/sites/upload_files/dit/files/NPE_Notification.pdf. 
Table 2. Translog stochastic production frontier estimation results.

\begin{tabular}{|c|c|c|}
\hline \multirow{2}{*}{ Variables } & \multicolumn{2}{|c|}{ Equation (1) } \\
\hline & Co-efficients & t-values \\
\hline Constant & $-0.745^{* * *}$ & -2.804 \\
\hline $\log K_{i t}$ & 0.101 & 1.244 \\
\hline $\log L_{i t}$ & $0.525^{* * *}$ & 4.399 \\
\hline $\log M_{i t}$ & $0.679^{* * *}$ & 9.449 \\
\hline$t_{i t}$ & $0.105^{* * * *}$ & 2.676 \\
\hline $0.5\left(\log K_{i t}\right)^{2}$ & $-0.079^{* * *}$ & -4.695 \\
\hline $0.5\left(\log L_{i t}\right)^{2}$ & $-0.086^{* *}$ & -2.551 \\
\hline $0.5\left(\log M_{i t}\right)^{2}$ & $0.069^{* * *}$ & 4.144 \\
\hline $0.5 t_{i t}^{2}$ & $-0.014^{* *}$ & -2.237 \\
\hline$\left(\log K_{i t}\right)\left(\log L_{i t}\right)$ & $0.069^{* * *}$ & 3.420 \\
\hline$\left(\log K_{i t}\right)\left(\log M_{i t}\right)$ & -0.020 & -1.448 \\
\hline$\left(\log K_{i t}\right) t_{i t}$ & $-0.014^{* *}$ & -2.222 \\
\hline$\left(\log L_{i t}\right)\left(\log M_{i t}\right)$ & $-0.027^{*}$ & -1.719 \\
\hline$\left(\log L_{i t}\right) t_{i t}$ & 0.002 & 0.252 \\
\hline$\left(\log M_{\mathrm{it}}\right) t_{i t}$ & 0.007 & 1.222 \\
\hline \multicolumn{3}{|c|}{ Inefficiency model } \\
\hline Constant & $-8.318^{* * *}$ & -3.756 \\
\hline$t_{i t}$ & $0.409^{* * *}$ & 3.480 \\
\hline $\mathrm{TD}$ & -0.170 & -0.611 \\
\hline KIMPINT & $-1.694^{* * *}$ & -14.294 \\
\hline IMPINT & $1.604^{* * * *}$ & 5.645 \\
\hline TECHIMP & $-7.812^{* * *}$ & -2.694 \\
\hline RNDINT & $1.232^{* * *}$ & 3.851 \\
\hline LSALES & $-0.652^{* * *}$ & -90.247 \\
\hline FOR & $-3.411^{* * * *}$ & -3.361 \\
\hline PUB & $0.268^{* * *}$ & 9.867 \\
\hline Sigma-squared & $1.944^{* * * *}$ & 4.460 \\
\hline Gamma & $0.972^{* * *}$ & 124.687 \\
\hline Log-likelihood & -260.298 & \\
\hline
\end{tabular}

Note: ${ }^{* * *}$ statistically significant at $1 \%$ level; ${ }^{* *}$ statistically significant at $5 \%$ level; ${ }^{*}$ statistically significant at $10 \%$ level.

Table 3. No technical inefficiency $\mathrm{H}_{0}$ (gamma = all deltas = 0).

\begin{tabular}{cccccc}
\hline Sector/Sub-sectors & ULLF & RLLF & Test statistic & Critical value $^{*}$ & Decision $^{*}$ \\
\hline Equation (1) & -260.298 & -282.65 & 44.704 & 10.371 & $\mathrm{H}_{0}$ Rejected \\
\hline
\end{tabular}

Note: ${ }^{*}$ Critical value of the test statistic at $5 \%$ level of significance. The test statistic follows a mixed Chi-square distribution, so critical values are taken from [47]. 
of firms in the electronics sector. This might also be due to the way in which firms report R \& D expenditure in India in order to avail fiscal benefits (Driffield and Kambhampati [48]; Mani [49]). The co-efficients of firm size (LSALES) is negative and significant for the electronics sector. This implies that the level of technical efficiency is higher for larger firms as such firms can benefit from economies of scale. A larger firm may have an access to superior quality of inputs, which helps to enhance its efficiency level. The co-efficient of FOR is negative and statistically significant for the electronics sector which indicates that other things remaining unchanged, a foreign firm is technically more efficient than a domestically owned firm. The level of technical efficiency is lower for the public sector firms in comparison with other firms as the co-efficient of PUB is positive and statistically significant for the electronics sector.

\section{Conclusion}

This study finds that the electronics sector of India has experienced an improvement in technical progress during 2002-10. But the average level of technical efficiency of firms has declined during the same period. This indicates that a number of firms have failed to appropriate benefits of technical progress. There has not been any significant improvement in average technical efficiency of firms after the implementation of ITA of WTO in the year 2005. Imports of capital goods and technology have favourable impact on technical efficiency but the firms which are more dependent on imported raw materials are less efficient. Such firms are primarily engaged in assembling of imported electronic products with very limited manufacturing activities. However, the results of this study are only indicative since the sample size for our study is not very large. Results also show a positive relationship between size of a firm and its level of technical efficiency mainly due to economies of scale. It has been observed that foreign firms in the Indian electronics sector have higher technical efficiencies than domestic firms and the level of technical efficiency is lower for public sector firms.

\section{References}

[1] Kalirajan, K.P., Obwona, M.B. and Zhiao, S. (1996) A Decomposition of Total Factor Productivity Growth: The Case of Chinese Agricultural Growth before and after Reforms. American Journal of Agricultural Economics, 78, 331-338. http://dx.doi.org/10.2307/1243706

[2] Abramovitz, M. (1956) Resource and Output Trends in the United States Since 1870. American Economic Review, 46, 5-23.

[3] Kumbhakar, S.C. and Knox Lovell, C.A. (2000) Stochastic Frontier Analysis. Cambridge University Press, Cambridge. http://dx.doi.org/10.1017/CBO9781139174411

[4] Joseph, K.J. (2005) Strategic Approach to Strengthening the International Competitiveness in Knowledge Based Industries: Electronics Industry. Microeconomics Working Papers 22102, East Asian Bureau of Economic Research. http://ideas.repec.org/p/eab/microe/22102.html

[5] Joseph, K.J. and Parayil, G. (2008) Can Trade Liberalization Bridge the Digital Divide? Assessing the Information Technology Agreement. Economic and Political Weekly, 43, 46-53.

[6] Kallummal, M. (2012) Process of Trade Liberalization under the Information Technology Agreement (ITA): The Indian Experience. Working Paper, Centre for WTO Studies, Indian Institute of Foreign Trade, New Delhi. http://wtocentre.iift.ac.in/workingpaper/Working\%20Paper3.pdf

[7] Mani, S. (2014) Emergence of India as the World Leader in Computer and Information Services. Economic and Political Weekly, 49, 51-61.

[8] Krishna, P. and Mitra, D. (1998) Trade Liberalization, Market Discipline and Productivity Growth: New Evidence from India. Journal of Development Economics, 58, 447-462. http://dx.doi.org/10.1016/S0304-3878(98)00074-1

[9] Topalova, P. (2004) Trade Liberalization and Firm Productivity: The Case of India. Working Paper, WP/04/28, International Monetary Fund. https://www.imf.org/external/pubs/ft/wp/2004/wp0428.pdf

[10] Sivadasan, J. (2006) Productivity Consequences of Product Market Liberalization: Micro-Evidence from Indian Manufacturing Sector Reforms. Ross School of Business Paper No.1062, 1-47.

https://deepblue.lib.umich.edu/bitstream/handle/2027.42/49240/1062-Sivadasan.pdf?sequence=1\&isAllowed=y

[11] Topalova, P. and Khandelwal, A. (2011) Trade Liberalization and Firm Productivity: The Case of India. The Review of Economics and Statistics, 93, 995-1009. http://dx.doi.org/10.1162/REST_a_00095

[12] Ray, S. (2004) MNEs, Strategic Alliances and Efficiency of Firms: Emerging Trends. Economic and Political Weekly (Review of Industry and Management), 39, 434-440. 
[13] Siddharthan, N.S. and Lal, K. (2004) Liberalization, MNE and Productivity of Indian Enterprises. Economic and Political Weekly (Review of Industry and Management), 39, 448-452.

[14] Goldar, B., Renganathan, V. and Banga, S. (2004) Ownership and Efficiency in Engineering Firms: 1990-91 to 1999-2000. Economic and Political Weekly, (Review of Industry and Management), 39, 441-447.

[15] Banga, R. (2004) Impact of Japanese and US FDI on Productivity Growth: A Firm-Level Analysis. Economic and Political Weekly (Review of Industry and Management), 39, 453-460.

[16] Kato, A. (2009) Product Market Competition and Productivity in the Indian Manufacturing Industry. Journal of Development Studies, 45, 1579-1593. http://dx.doi.org/10.1080/00220380802663575

[17] Balakrishnan, P. and Suresh Babu, M. (2000) Trade Liberalization and Productivity Growth in Manufacturing-Evidence from Firm-Level Panel Data. Economic and Political Weekly, 35, 3679-3682.

[18] Srivastava, V. (2001) The Impact of India’s Economic Reforms on Industrial Productivity, Efficiency and Competitiveness. National Council of Applied Economic Research, New Delhi.

[19] Balakrishnan, P., Parameswaran, M., Pushpangadan, K. and Suresh Babu, M. (2006) Liberalization, Market Power and Productivity Growth in Indian Industry. Journal of Economic Policy Reform, 9, 55-73. http://dx.doi.org/10.1080/13841280500513076

[20] Datta Chaudhuri, D. (2010) Productivity Growth of Indian Manufacturing Firms in an Era of Economic Reforms: A Review. Productivity, 51, 248-253.

[21] Majumdar, R. (2010) Did Liberalization Impact Productivity of the Indian Electronics Hardware Industry? International Journal of the Economics of Business, 17, 253-273. http://dx.doi.org/10.1080/13571516.2010.483093

[22] Majumdar, R. (2010) A Stochastic Approach to Measure Performance of the Indian Electronics Hardware Industry after Liberalization. Journal of Manufacturing Technology Management, 21, 539-555. http://dx.doi.org/10.1108/17410381011046959

[23] Dwivedi, A. (2012) Effect of FDI and Trade on Productivity in Indian Electronics Firms. The Indian Economic Journal, 60, 76-90.

[24] Solow, R.M. (1957) Technical Change and Aggregate Production Function. The Review of Economics and Statistics, 39, 312-320. http://dx.doi.org/10.2307/1926047

[25] Leibenstein, H. (1966) Allocative Efficiency vs. X-Efficiency. American Economic Review, 56, 392-415.

[26] Farell, M.J. (1957) The Measurement of Productive Efficiency. Journal of Royal Statistical Society, Series A, (General), 120, 253-290. http://dx.doi.org/10.2307/2343100

[27] Charnes, A., Cooper, W.W. and Rhodes, E. (1978) Measuring the Efficiency of Decision-Making Units. European Journal of Operation Research, 2, 429-444. http://dx.doi.org/10.1016/0377-2217(78)90138-8

[28] Aigner, D.J. and Chu, S.F. (1968) On Estimating the Industry Production Function. American Economic Review, 58, 826-839.

[29] Meeusen, W. and van Den Broeck, J. (1977) Efficiency Estimation from Cobb-Douglas Production Functions with Composed Error. International Economic Review, 18, 435-444. http://dx.doi.org/10.2307/2525757

[30] Aigner, D.J., Lovell, C.A.K. and Schmidt, P. (1977) Formulation and Estimation of Stochastic Frontier Production Function Models. Journal of Economics, 6, 21-37. http://dx.doi.org/10.1016/0304-4076(77)90052-5

[31] Battese, G.E. and Corra, G.S. (1977) Estimation of a Production Frontier Model: With Application to the Pastoral Zone off Eastern Australia. Australian Journal of Agricultural Economics, 21, 169-179. http://dx.doi.org/10.1111/j.1467-8489.1977.tb00204.x

[32] Pitt, M.M. and Lee, L.-F. (1981) The Measurement and Sources of Technical Inefficiency in the Indonesian Weaving Industry. Journal of Development Economics, 9, 43-64. http://dx.doi.org/10.1016/0304-3878(81)90004-3

[33] Schmidt, P. and Sickles, R.C. (1984) Production Frontiers and Panel Data. Journal of Business and Economic Statistics, 2, 367-374.

[34] Cornwell, C., Schmidt, P. and Sickles, R.C. (1990) Production Frontiers with Cross-Sectional and Time-Series Variation in Efficiency Levels. Journal of Econometrics, 46, 185-200. http://dx.doi.org/10.1016/0304-4076(90)90054-W

[35] Kumbhakar, S.C. (1990) Production Frontiers, Panel Data and Time-Varying Technical Inefficiency. Journal of Econometrics, 46, 201-212. http://dx.doi.org/10.1016/0304-4076(90)90055-x

[36] Battese, G.E. and Coelli, T.J. (1992) Frontier Production Functions, Technical Efficiency and Panel Data: With Application to Paddy Farmers in India. Journal of Productivity Analysis, 3, 153-169. http://dx.doi.org/10.1007/BF00158774

[37] Kumbhakar, S.C., Ghosh, S. and McGuckin, T.J. (1991) Generalized Production Frontier Approach for Estimating De- 
terminants of Inefficiency in US Dairy Farms. Journal of Business and Economic Statistics, 9, 279-286.

[38] Huang, C.J. and Liu, J.-T. (1994) Estimation of a Non-Neutral Stochastic Frontier Production Function. Journal of Productivity Analysis, 5, 171-180. http://dx.doi.org/10.1007/BF01073853

[39] Battese, G.E. and Coelli, T.J. (1995) A Model for Technical Efficiency Effects in a Stochastic Frontier Production Function for Panel Data. Empirical Economics, 20, 325-332. http://dx.doi.org/10.1007/BF01205442

[40] Tybout, J.R. (2000) Manufacturing Firms in Developing Countries: How Well Do They Do, and Why? Journal of Economic Literature, 38, 11-44. http://dx.doi.org/10.1257/jel.38.1.11

[41] Coelli, T.J. (1996) A Guide to FRONTIER Version 4.1: A Computer Program for Stochastic Frontier Production and Cost Function Estimation. CEPA Working Paper No. 7/96, Department of Econometrics, University of New England, Armidale. http://www.uq.edu.au/economics/cepa/frontier.php

[42] Nagaraj, R. (2011) Industrial Performance, 1991-2008: A Review. In: Nachane, D.M., Ed., India Development Report, Oxford University Press, New Delhi, 69-80.

[43] Girma, S., Greenway, D. and Wakelin, K. (2001) Who Benefits from Foreign Direct Investment in the U.K.? Scottish Journal of Political Economy, 48, 119-133. http://dx.doi.org/10.1111/1467-9485.00189

[44] Lipsey, R.E. and Sjoholm, F. (2001) Foreign Direct Investment and Wages in Indonesian Manufacturing. Working Paper No. 8299, National Bureau of Economic Research, Cambridge. http://www.agi.or.jp/workingpapers/WP2001-02.pdf http://dx.doi.org/10.3386/w8299

[45] Jang, S.-L., Weng, M.-H. and Wang, Y. (2005) Industrial Diversification and Its Impact on Productivity Growth in Taiwan's Electronics Industry. Asian Economic Journal, 19, 423-443. http://dx.doi.org/10.1111/j.1467-8381.2005.00220.x

[46] Lundvall, K. and Battese, G.E. (2000) Firm Size, Age and Efficiency: Evidence from Kenyan Manufacturing Firms. Journal of Development Studies, 36, 146-163. http://dx.doi.org/10.1080/00220380008422632

[47] Kodde, D.A. and Palm, F.C. (1986) Wald Criteria for Jointly Testing Equality and Inequality Restrictions. Econometrica, 54, 1243-1248. http://dx.doi.org/10.2307/1912331

[48] Driffield, N.L. and Kambhampati, U.S. (2003) Trade Liberalization and the Efficiency of Firms in Indian Manufacturing. Review of Development Economics, 7, 419-430. http://dx.doi.org/10.1111/1467-9361.00200

[49] Mani, S. (2014) Innovation: The World’s Most Generous Tax Regime. In: Jalan, B. and Balakrishnan, P., Eds., Politics Trumps Economics-The Interface of Economics and Politics in Contemporary India, Rupa Publications India Ltd., New Delhi, 155-169.

[50] Unel, B. (2003) Productivity Trends in India's Manufacturing Sectors in the Last Two Decades. IMF Working Paper No. WP/03/22, International Monetary Fund, Washington DC. https://www.imf.org/external/pubs/ft/wp/2003/wp0322.pdf

[51] Banga, R. and Goldar, B.N. (2007) Contribution of Services to Output Growth and Productivity in Indian Manufacturing: Pre and Post Reforms. Economic and Political Weekly, 42, 2769-2777. 


\section{Appendix}

The gross fixed asset (GFA) data are measured at book-value which has a defect that in a period of rising prices, the older assets are recorded as much lower prices than similar assets of new vintage. The perpetual inventory accumulation (PIA) method requires the estimation of GFA for the benchmark year (i.e. 2002-03) at replacement cost new (i.e. gross value or purchase value of the asset suitably adjusted for changes in prices over time). So, proper estimation of benchmark capital stock requires detailed information on the age structure of capital assets existing at the end of the benchmark year. Since this information is not available, following Goldar et al. [14] a crude estimate of the replacement value of fixed capital stock existing at the end of 2002-03 in each firm, has been made by applying a rule of thumb. The 100 firms in the sample have been divided into three groups: old, new and very new. Companies have been classified according to the date of incorporation: (i) companies incorporated before 1980 are classified as old companies, (ii) companies incorporated during 1980s are classified as new companies and (iii) companies incorporated during 1990s are classified as very new companies. To get the replacement value of fixed assets, GFA of the companies in 2002-03 has been multiplied by 3 for old companies, by 2 for new companies and by 1.5 for very new companies.

The difference in book value of GFA of each company, year to year, is considered as nominal investment. Nominal investment so obtained is deflated using the wholesale price indices for 'machinery and machine tools' $(1993-94=100)$. Computed real gross investments are then successively added from the second year to the benchmark capital value $\left(K_{0}\right)$ to arrive at real capital stock series.

Once the value of real gross fixed capital stock for the benchmark year $K_{0}$ is calculated, the values of the capital stock for each successive year is calculated using the relationship

$$
K_{t}=K_{t-1}+I_{t}-d K_{t-1}=(1-d) K_{t-1}+I_{t}
$$

where, $K_{t}=$ Real fixed capital stock at period $t$;

$K_{t-1}=$ Real fixed capital stock for period $t-1$;

$I_{t}=$ Real gross fixed capital formation in period $t$;

$d=$ Rate of depreciation.

In this study, a straight line method of depreciation has been followed under which the amount written off each year is taken as a constant percentage of the real gross fixed capital stock of the previous year i.e. $K_{t-1}$. The value of $d$ is taken as 5\% per annum following the studies of Unel [50], Banga and Goldar [51] and Majumdar [21]. 